\title{
Indicators of Buying influence in business Markets Perceived by Marketing Students
}

\author{
Angelo R. Santos
}

Ph. DBA Candidate in Nueva Ecija University of Science and Technology

Instructor, College of Management and Business Technology, Nueva Ecija University of Science and Technology, Nueva Ecija, Philippines

15angelosantos@gmail.com/angelosantos@neust.edu.ph

\begin{abstract}
Marketing experts studied the processes and behaviors that business customers used in their buying activities, and enabled research to better understand and maintain their business customers. This paper determined the indicators of buying influence in business markets in terms of: environmental influences, organizational influences, situational influences, interpersonal influences and individual influences; and determined the level of influence to the buying decision perceived by marketing students. This paper used descriptive method. A total of 317 students (219 Female and 98 Male) taking up Bachelor of Science in Business Administration Major in Marketing Management from State Universities and Colleges in Nueva Ecija were surveyed in this paper.
\end{abstract}

Keywords-Buying Decision, Buying Influence, Marketing, Buying Behavior, Environmental Influences, Organizational Influences, Cultural Influences.

\section{INTRODUCTION}

Marketing experts studied the processes and behaviors that business customers used in their buying activities, and enabled research to better understand and maintain their business customers. Consumer buying behavior is very dynamic, and it can vary considerably among different product categories and purchasing decisions because buyers use different criteria and characteristics in the decision process (Sumi \&Kabir, 2010). The shift from buying behavior related to product acquisition to buying behavior related to the buying situation is a shift from product properties to point of sale experiences (Clement, 2007).Through maintaining the price standard doing more enticing advertising, offering more discount, and serving customers well, the convenience store will promote more engagement, customers, recognition, and thus raise consumer buying intention in the same way (Andreti et al., 2013).

The company's emerging marketing strategy should be equal to all customers and show a proper amount of specific product information to digest the product information, which will improve the consumer's intention to buy (Lin \& Chen, 2006). The social influence of high-quality reviews provided by previous consumers can have a clear and positive effect on the decision-making of potential consumers (Kim \& Srivastava, 2007). Worldwide, there has been a dramatic increase in environmental awareness, with consumers changing their behavior to incorporate environmental considerations into lifestyle choices, as these include buying decisions for consumers based on how well products meet their needs and affect the natural environment (Barber et al., 2009).

In light with the foregoing insights, the researcher assessed the indicators of buying influence in business markets. Further, the researcher determined the level of influence perceived by the marketing students in Nueva Ecija.

\section{CONCEPTUAL FRAMEWORK}

Consumers in collectivist markets rely heavily on interpersonal influences in information, whereas consumers in individualist markets refrain from associating themselves with interpersonal influences in information (Shukla, 2011). By exploring the planned and impulsive buying behavior of consumers across cultures, it had been identified that when shopping with family and friends is likely to influence satisfaction after purchase (Lee \& Kacen, 2008).

Environmental labeling is an important means of reaching and communicating to consumers' environmental justifications for products, since a relatively large number of consumers are always reading labels and considering the information provided to be correct (D'Souza et al., 2006).

\section{OBJECTIVES OF THE STUDY}

This paper determined the indicators of buying influence in business markets in terms of: environmental influences, organizational influences, situational influences, 
interpersonal influences and individual influences; and determined the level of influence to the buying decision perceived by marketing students.

\section{METHODOLOGY}

This paper used descriptive method, as it is a basic approach to analysis that explores the situation as it occurs in its present state (Williams, 2007).A total 317marketing studentsfrom State Universities and colleges in Nueva Ecija were involved in this study. They were composed of 219 female and 98 male students taking up Bachelor of Science in Business Administration Major in Marketing Management. This paper used survey research since it integrates scientific methods through critical analysis and evaluation of source materials, analysis and interpretation of data, and generalization and prediction (Salaria, 2012).

\section{RESULTS AND DISCUSSIONS}

Table 1. Environmental Influence Than Can Affect Business

\begin{tabular}{|c|c|c|}
\hline \multicolumn{3}{|l|}{ Market } \\
\hline Supply Conditions & $M$ & VI \\
\hline $\begin{array}{l}\text { 1. Assurance of the supply of raw } \\
\text { materials is very important to } \\
\text { manufacture products. }\end{array}$ & 3.46 & VI \\
\hline $\begin{array}{l}\text { 2. Ensuring continuous supply to the } \\
\text { customers leads to }\end{array}$ & 3.22 & MI \\
\hline $\begin{array}{l}\text { 3. There is a need for big warehouse to } \\
\text { store big number of supplies. }\end{array}$ & 2.93 & MI \\
\hline Competitive Developments & & \\
\hline $\begin{array}{l}\text { 4. Technological advancements allow a } \\
\text { company to gain competitive } \\
\text { advantage. }\end{array}$ & 2.78 & MI \\
\hline $\begin{array}{l}\text { 5. Technical service can change the } \\
\text { consumer preferences and shift } \\
\text { demand in favor of the new innovation }\end{array}$ & 3.36 & VI \\
\hline $\begin{array}{l}\text { 6. New ownership of a supplier company } \\
\text { can become more attractive to a } \\
\text { business customer. }\end{array}$ & 2.85 & MI \\
\hline Social Responsibility & & \\
\hline $\begin{array}{l}\text { 7. Logistics companies should deliver } \\
\text { relief goods for free to calamity areas. }\end{array}$ & 3.21 & MI \\
\hline $\begin{array}{l}\text { 8. A part of company's profit must be set } \\
\text { aside for environment protection and } \\
\text { community programs. }\end{array}$ & 3.53 & VI \\
\hline Average Mean & 3.17 & MI \\
\hline
\end{tabular}

\section{Legend}

$3.25-4.00$

$2.50-3.24$

$1.75-2.49$

$1.00-1.74$
Verbal Interpretation (VI)

Very Important (VI)

Moderately Important (MI)

Slightly Important (SI)

Low Importance (LI)
Table 1 shows how environmental influence can affect business market. Environmental influence includes supply conditions, competitive developments, and social responsibility. Based on the results, environmental influence got an average mean of 3.17 with a verbal interpretation of 'moderately important'. It further explained that under this influence item $1(M=3.46), 5(M=3.36)$, and $7(M=3.53)$ got the highest means all with verbal interpretations of "very important'. This implies that under environmental influences assurance of supply of raw material (supply conditions), technical service (competitive developments), and a part company's profit for environment and community programs (social responsibility) are found to be important indicators of buying influence in business market.

Table 2. Organizational Influences Than Can Affect Business Market

\begin{tabular}{|c|c|c|}
\hline Objectives & $M$ & VI \\
\hline $\begin{array}{l}\text { 1. Buying company's objectives } \\
\text { influence the buying behavior of a } \\
\text { business. }\end{array}$ & 2.83 & MI \\
\hline \multicolumn{3}{|l|}{ Policies } \\
\hline $\begin{array}{l}\text { 2. A company that has a policy of buying } \\
\text { from proven suppliers would have the } \\
\text { edge among other companies. }\end{array}$ & 3.07 & MI \\
\hline $\begin{array}{l}\text { 3. Multinational companies must require } \\
\text { their local companies to buy supplies } \\
\text { only from accredited providers. }\end{array}$ & 2.61 & MI \\
\hline \multicolumn{3}{|l|}{ Procedures } \\
\hline $\begin{array}{l}\text { 4. Issuing purchase order can be assigned } \\
\text { to an administrative staff. }\end{array}$ & 3.73 & VI \\
\hline $\begin{array}{l}\text { 5. More rigid bidding participations are } \\
\text { required in government transactions. }\end{array}$ & 3.56 & VI \\
\hline \multicolumn{3}{|l|}{ Organizational Structures } \\
\hline $\begin{array}{l}\text { 6. Understanding the perspectives and } \\
\text { needs of each stakeholder in the } \\
\text { company is necessary. }\end{array}$ & 3.46 & VI \\
\hline $\begin{array}{l}\text { 7. A company should have a coordination } \\
\text { map of who to seek approval from and } \\
\text { consultation for what. }\end{array}$ & 3.76 & VI \\
\hline Skills & & \\
\hline
\end{tabular}




\begin{tabular}{|c|c|c|c|}
\hline & $\begin{array}{l}\text { The applicants should be proficient in } \\
\text { English for both oral and written } \\
\text { communications. }\end{array}$ & 2.27 & SI \\
\hline \multicolumn{2}{|r|}{ System } & & \\
\hline 9. & $\begin{array}{l}\text { A company entails a more } \\
\text { collaborative relationship with greater } \\
\text { competencies needed from the } \\
\text { suppliers. }\end{array}$ & 3.39 & MI \\
\hline & Average Mear & 3.19 & MI \\
\hline
\end{tabular}

\section{Legend}

$3.25-4.00$

$2.50-3.24$

$1.75-2.49$

$1.00-1.74$

Verbal Interpretation (VI)
Very Important (VI)
Moderately Important (MI)
Slightly Important (SI)
Low Importance (LI)

Table 2 shows how organizational influence can affect business market. Organizational influence includes objectives, policies, procedures, organizational structures, skills, and system. Based on the results, organizational influence got an average mean of 3.19 with a verbal interpretation of 'moderately important'. It further showed that under this influence items $4(M=3.73), 5(M=3.56), 6$ $(M=3.46)$ and $7(M=3.76)$ got the highest means all with verbal interpretations of 'very important'. This implies that organizational influence procedures and organizational structures are very important indicators of buying influence in business market.

\begin{tabular}{|c|c|c|}
\hline \multicolumn{3}{|c|}{$\begin{array}{c}\text { Table 3. Situational Influences Than Can Affect Business } \\
\text { Market }\end{array}$} \\
\hline Time & $M$ & VI \\
\hline $\begin{array}{l}\text { 1. Time is very important that it could } \\
\text { affect losing revenue and profiting in } \\
\text { the process. }\end{array}$ & 2.41 & SI \\
\hline $\begin{array}{l}\text { 2. Manpower services should guarantee } \\
\text { on time process. }\end{array}$ & 3.19 & MI \\
\hline \multicolumn{3}{|l|}{ Financial Standing } \\
\hline $\begin{array}{l}\text { 3. Empower higher authorities to give } \\
\text { credit approval }\end{array}$ & 3.12 & MI \\
\hline $\begin{array}{l}\text { 4. Higher credit amount should be } \\
\text { deliberated by the credit committee to } \\
\text { attain minimal credit risk. }\end{array}$ & 2.97 & MI \\
\hline \multicolumn{3}{|l|}{ Availability } \\
\hline $\begin{array}{l}\text { 5. Availability of inventories should } \\
\text { always be managed. }\end{array}$ & 3.56 & VI \\
\hline Exclusivity & & \\
\hline
\end{tabular}

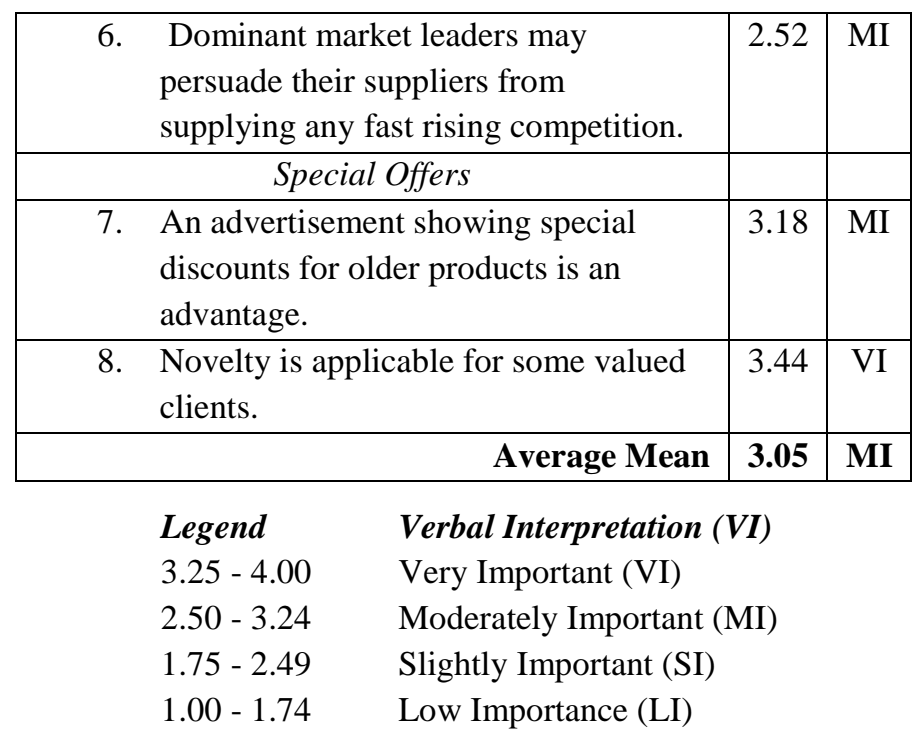

Table 3 shows how situational influence can affect business market. Situational influence includes time, financial standing, availability, exclusivity, and special offers. Based on the results, environmental influences got an average mean of 3.05 with a verbal interpretation of 'moderately important'. It further explained that under this influence items $5(M=3.56)$ and $8(M=3.44)$ got the highest means all with verbal interpretations of 'very important'. This suggests that under situational influence availability of inventories (availability) and novelty offers (special offers) are found to be important indicators of buying influence in business market.

\begin{tabular}{|c|c|c|}
\hline \multicolumn{3}{|l|}{ Market } \\
\hline Interests & $M$ & VI \\
\hline $\begin{array}{l}\text { 1. Interpersonal relationship is necessary } \\
\text { for decision making in business. }\end{array}$ & 3.79 & VI \\
\hline $\begin{array}{l}\text { 2. Different departments can be created } \\
\text { intently for the sole purpose of their } \\
\text { interests in decision making. }\end{array}$ & 3.11 & MI \\
\hline \multicolumn{3}{|l|}{ Authority } \\
\hline $\begin{array}{l}\text { 3. Authority level of different people can } \\
\text { either accelerate or slow down the } \\
\text { buying process. }\end{array}$ & 2.88 & MI \\
\hline $\begin{array}{l}\text { 4. Higher ranks equate to a higher } \\
\text { authority level of the purchasing } \\
\text { department. }\end{array}$ & 3.44 & VI \\
\hline \multicolumn{3}{|l|}{ Status } \\
\hline 5. Status of different people gives & 3.22 & MI \\
\hline
\end{tabular}




\begin{tabular}{|c|c|c|}
\hline different preferences. & & \\
\hline $\begin{array}{l}\text { 6. An established suppliers is more } \\
\text { favorable than a new supplier. }\end{array}$ & 3.46 & VI \\
\hline \multicolumn{3}{|l|}{ Empathy } \\
\hline $\begin{array}{l}\text { 7. Being likable, amiable, and fair is more } \\
\text { like to generate facilitating working } \\
\text { relationship with coworkers. }\end{array}$ & 3.69 & VI \\
\hline $\begin{array}{l}\text { 8. Empathy affects negotiation with } \\
\text { established suppliers. }\end{array}$ & 3.53 & VI \\
\hline \multicolumn{3}{|l|}{ Persuasiveness } \\
\hline $\begin{array}{l}\text { 9. Well-research business case is viable } \\
\text { for the management to continue with a } \\
\text { planned purchase. }\end{array}$ & 3.24 & $\mathrm{MI}$ \\
\hline $\begin{array}{l}\text { 10. Persuasiveness promotes higher } \\
\text { performance attributes to the suppliers. }\end{array}$ & 3.44 & VI \\
\hline Average Mean & 3.38 & VI \\
\hline
\end{tabular}

\section{Legend}

$3.25-4.00$

Verbal Interpretation (VI)

$2.50-3.24$

Very Important (VI)

$1.75-2.49$

Moderately Important (MI)

$1.00-1.74$

Slightly Important (SI)

Low Importance (LI)

Table 4 shows how interpersonal influence can affect business market. interpersonal influence includes interests, authority, status, empathy, and persuasiveness. Based on the results, interpersonal influence got an average mean of 3.38 with a verbal interpretation of 'very important'. It further exhibited that under this influence items $1(M=3.79), 4(M$ $=3.44), 6(M=3.46), 7(M=3.69), 8(M=3.53)$, and $10(M$ $=3.44)$ got the highest means all with verbal interpretations of 'very important'. This indicates that under interpersonal influence interests, authority, status, empathy, and persuasiveness are very important indicators of buying influence in business market. Thus, interpersonal relationship is necessary, credit committee should be created, give favor to established suppliers, show empathy and good personality, and display persuasiveness.

Table 5. Individual Influences Than Can Affect Business Market

\begin{tabular}{|c|c|c|}
\hline Age & $M$ & VI \\
\hline $\begin{array}{l}\text { 1. The age of the buyer is an important } \\
\text { factor in the business buying decision. }\end{array}$ & 3.13 & $\mathrm{MI}$ \\
\hline $\begin{array}{l}\text { 2. Younger employees tend to be more } \\
\text { informative, analytic, and useful in } \\
\text { making purchase. }\end{array}$ & 3.83 & VI \\
\hline
\end{tabular}

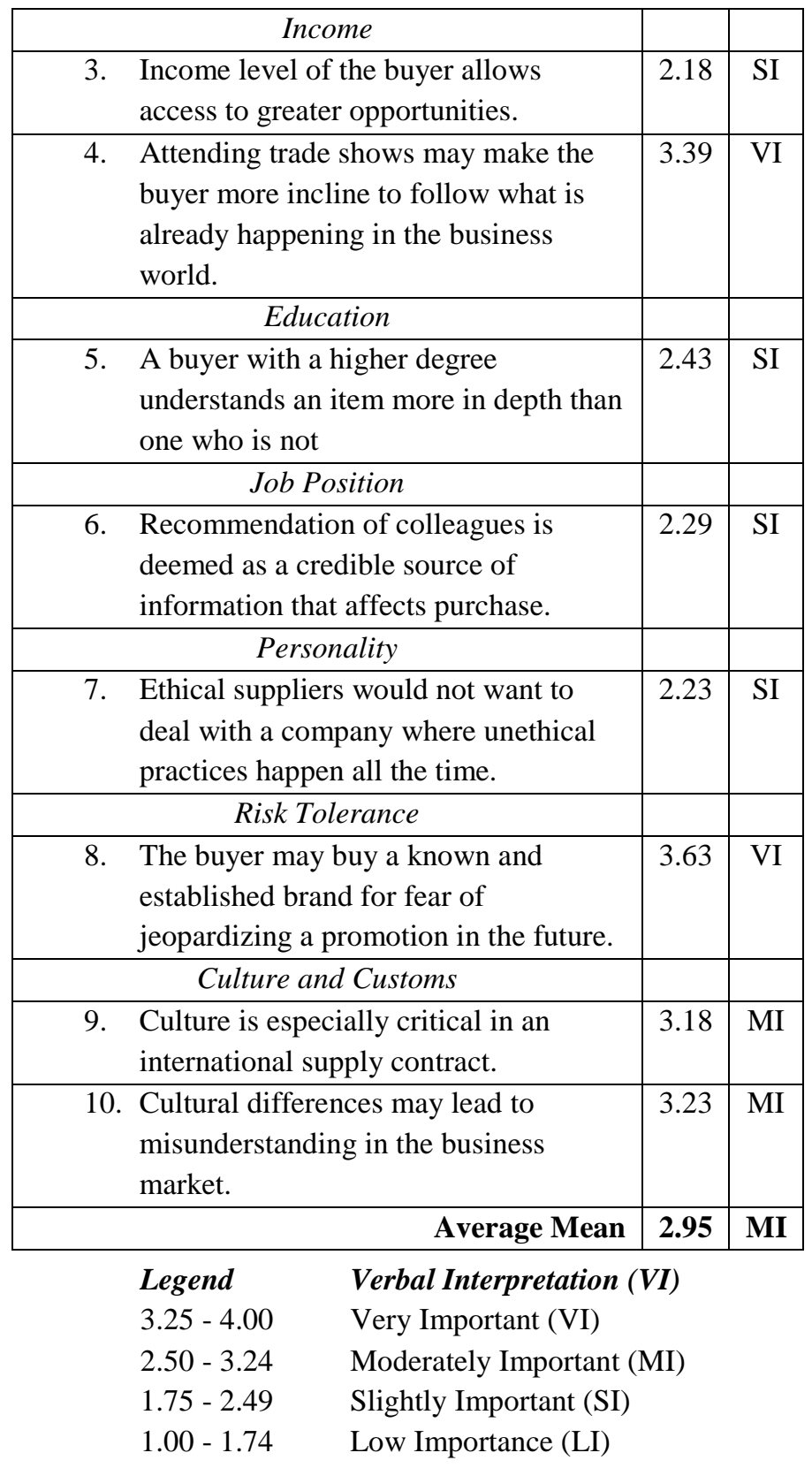

Table 5 shows how individual influence can affect business market. Individual influence includes age, income, education, job position, personality, risk tolerance, and culture and customs. Based on the results, individual influence got an average mean of 2.89 with a verbal interpretation of 'moderately important'. It further described that under this influence items $2(M=3.83), 4(M=3.39)$, and8 $(M=3.63)$ got the highest means all with verbal interpretations of "very important'. This recommends that under individual influence age, income, and risks tolerance are important indicators of buying influence in business market. Further, these indicators 
describe that younger employees are more informative and analytical, attending trade shows is necessary to keep updated, and buyer relies on a known and established brand/supplier. influences since profitability does not only come from operations but also from how purchasing is managed in a company to maximize the value to the stockholders.

\section{REFERENCES}

\begin{tabular}{|c|r|c|}
\hline \multicolumn{4}{|c|}{ Table 6. Level of Influence of the Different Indicators } \\
\hline Influences & $\boldsymbol{M}$ & Verbal Interp \\
\hline Environmental & 3.17 & Moderately \\
\hline Organizational & 3.19 & Moderately \\
\hline Situational & 3.05 & Moderately \\
\hline Interpersonal & 3.38 & \multicolumn{1}{c}{ Very Im } \\
\hline Individual & 2.95 & Moderately \\
Legend & Verbal Interpretation (VI) & Level of Influence \\
$3.25-4.00 \quad$ Very Important (VI) & Very Influential \\
$2.50-3.24 \quad$ Moderately Important (MI) & Somewhat Influential \\
$1.75-2.49 \quad$ Slightly Important (SI) & Slightly Influential \\
$1.00-1.74 \quad$ Low Importance (LI) & Not at all Influential
\end{tabular}

Table 6 shows the level of influence of the different indicators of the buying decision in the business market. Among five different buying influences, the highest average mean of 3.38 got by the interpersonal with a verbal interpretation of 'very influential'. This was followed by the organizational $(M=3.19)$, environmental $(M=3.17)$, situational $(M=3.05)$, and individual $(M=2.95)$, in respective order, and all are interpreted as 'somewhat influential'. The results suggest that all of the indicators are influential but only the interpersonal buying influence the most.

\section{CONCLUSIONS AND RECOMMENDATIONS}

Based on the findings, the researcher concluded that first, indicators of buying influence in the business market perceived by the marketing students are environmental, organizational, situational, interpersonal, and individual. Second, among these indicators, the interpersonal influence is said to be the most influential in in the business market. Last, specifically, indicators of buying influence focused on supply conditions, competitive developments, social responsibility, procedures, organizational structures, availability, special offers, authority, status, empathy, persuasiveness, age, income and risk tolerance.

It is then the researcher recommends that other indicators of buying influence should be take into consideration of the company for assessment and become their strengths. Further analysis should be conducted among the different buying 